\title{
INVESTIGATION OF HYGIENIC PROPERTIES OF MATERIALS FOR HOSPITAL UNDERWEAR
}

\author{
Igor Ivanov', Natalya Suprun ${ }^{1 *}$, Yulia Vashchenko'
}

Kyiv National University of Technologies \& Design, Kyiv, Ukraine,

*e-mail: suprun.knutd@ukr.net

Scientific paper

UDC: $687.2+677-037$

doi: $10.5937 /$ tekstind2001012l

\begin{abstract}
The influence of peculiarities of raw material composition and structure of traditional and innovative linen textile materials on their hygienic properties was investigated. Using the standardized and the developed methods, adapted to the peculiarities of the conditions of use of the hospital underwear, the characteristics of water absorption of the materials were experimentally determined.
\end{abstract}

Key words: hospital linen, hygienic properties, moisture absorption, moisture transfer.

\section{ISPITIVANJE HIGIJENSKIH SVOJSTAVA MATERIJALA ZA BOLNIČKO DONJE RUBLJE}

Apstrakt: Uticaj karakteristika sirovinskog sastava i strukture tradicionalnih i inovativnih lanenih tekstilnih materijala na njihova higijenska svojstva je ispitan. Upotrebom standardizovanih i razvijenih metoda, prilagođenih karakteristikama uslova upotrebe bolničkog donjeg rublja, eksperimentalno su određene karakteristike apsorpcije vode u materijalima.

Ključne reči: bolničko rublje, higijenska svojstva, apsorpcija vlage, prenos vlage.

\section{INTRODUCTION}

The use of hospital linen is necessary to prevent the spreading of infections in medical facilities [1]. Hospital linen is a product of multiple applications, which have to provide a comfortable and hygienic stay of patient during therapy. Nowadays the creation of comfortable and aesthetic hospital clothing with functional and structural elements that simplifies carrying out of medical procedures for the personal and patients has been actively engaged by both scientists and specialists in the field of clothing design. Such clothes are traditionally considered as adaptive. Its use by patients take it easier dressing and undressing, for medical staff - provides easy access to different parts of the body during medical or hygienic procedures.

Compared to household clothing, hospital clothing has to meet a number of specific requirements, which are determined by the particular course of the
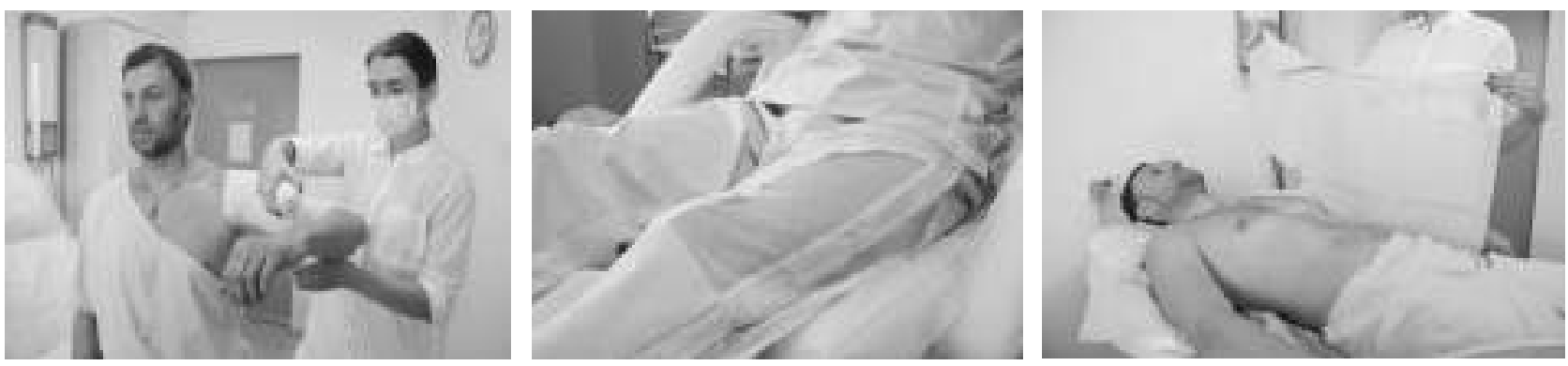

Figure 1: Examples of design solutions for hospital clothing 
disease and the methods of its treatment. Depending on the nature of the illness, different styles and design of such clothes are used (Fig.1).

Choice of materials for adaptive clothing is a complex process that includes medical, hygienic, technical and social requirements. The analysis of conditions of use of hospital underwear in clinics allowed defining its following main functions:

- providing a comfortable microclimate of underwear;

- protection against adverse environmental conditions (change of microclimate, biological factors, harmful chemicals, etc.);

- protection against mechanical damage (injuries, irritation, pressure ulcers);

- providing convenience to patients and medical staff in carrying out various medical procedures;

- creation of psychological comfort of the patient.

The materials of hospital underwear, above all, must ensure the proper functioning of the body - to absorb and remove liquid and vapor moisture freely from the surface of the body, to protect the body from cooling, overheating and contamination, to clean the skin from sweat and fat. In addition, they must be resistant to multiple washing, to abrasion, mechanical deformation, be light, soft to the touch, and free of toxic and allergic substances. An important factor is the price of the product, which determines the availability of adaptive clothing for a wide range of consumers.

Hospital linen for a long time traditionally has been made of cotton, linen and mixed (cotton + PES) fabrics. The advantages of these materials are their good hygienic properties - high hygroscopicity, cap- illarity, water absorption capacity. Also, they are quite durable, stable to numerous cycles of sterilization. The disadvantages include their ability to produce a large amount of dust as a result of friction, which is a source of pollution and causes allergic reactions in patients, as well as a leaky structure that does not limit the exchange of human life products between the patient and the environment. The occurrence of textiles from new types of fibers can significantly expand the range of fabrics for the manufacture of hospital linen.

Particular attention is paid to fabrics made of bamboo and Tencel fibers, taking into consideration valuable properties of these materials. Studies have shown that bamboo materials due to the porous fiber structure and the presence of the natural component "bamboo kun", which prevents the propagation of pathogenic microorganisms $[2,3]$, have a number of advantages over traditional cotton - higher hygroscopicity, antimicrobial properties, softness, drapery and other valuable consumer qualities. Fabrics from Tencel ${ }^{\circledR}$ fiber, which is made from eucalyptus wood, are highly hygroscopic, durable, soft, pleasure in touch, bacteriostatic [4].

The purpose of this work is to study the influence of the peculiarities of raw material composition and structure of traditional and innovative linen fabrics on their hygienic properties.

\section{EXPERIMENTAL}

\subsection{Materials}

As objects of study were selected five samples of fabrics for hospital underwear, which are different in the raw material composition and characteristics of structure (Fig.1 and Table 1).

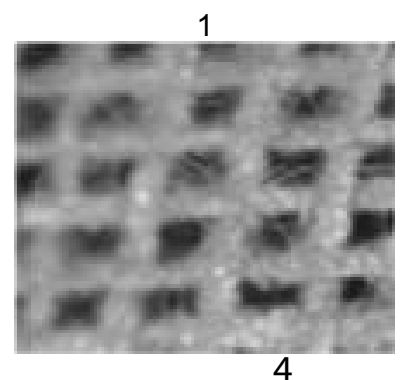

4

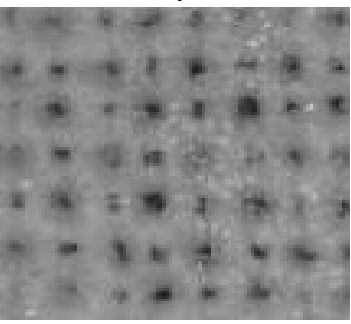

2
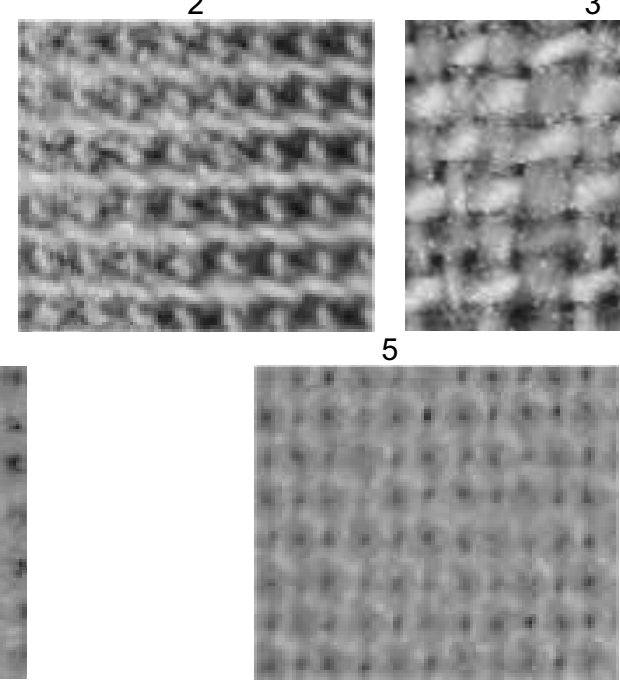

3

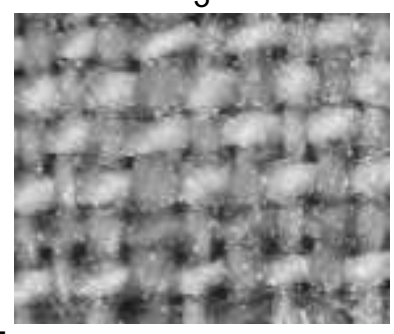

Figure 2: USB - imaging of fabrics for hospital underwear 
The surface density of fabrics was determined in accordance with Ukrainian Standard 3811-72; their thickness- ISO 5084: 2004. Determination of water absorption was made according to Ukrainian Standard 3816-81 ISO 811-81. Air permeability was determined on FF-12. The value of surface filling of fabrics $\mathrm{E}_{\mathrm{s}^{\prime}}$, was calculated as:

\section{RESULTS AND DISCUSSION}

Air permeability is an important characteristic of the hygienic properties of textile materials, which largely determines the parameters of the clothing microclimate (temperature, humidity, concentration of $\mathrm{CO}_{2}$ ), possess heat exchange and human well-being. Air permeability for the studied samples of fabrics

$$
E_{s}=d_{\text {warp }} \Pi_{\text {warp }}+d_{\text {weft }} \Pi_{\text {weft }}-0,01 d_{\text {warp }} \Pi_{\text {warp }} d_{\text {weft }} \Pi_{\text {weft }}
$$

$\Pi_{\text {warp }}, \Pi_{\text {weft }}-$ number of threads per $100 \mathrm{~mm}$ on warp/weft;

$d_{\text {warp }}, d_{\text {weft }}$ - diameter of warp/weft threads, was calculated as:

$$
\mathrm{d}=0,0357 \sqrt{\frac{\mathrm{T}}{\rho_{\mathrm{H}}}},
$$

$T$ - linear density of warp/weft threads, Tex;

$\rho_{H}$ - volume mass of the threads, $\mathrm{mg} / \mathrm{mm}^{3}$.

$$
R_{s}=100-E_{s},[\%]
$$

\begin{tabular}{|c|c|c|c|c|c|c|c|}
\hline 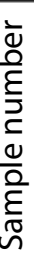 & $\begin{array}{l}\text { Raw material } \\
\text { composition, \% }\end{array}$ & $\begin{array}{c}\text { Surface } \\
\text { density, g/ } \\
\mathrm{m}^{2}\end{array}$ & 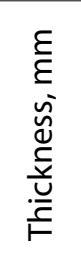 & $\begin{array}{c}\text { The number } \\
\text { of threads per } \\
100 \mathrm{~mm} \text { on } \\
\text { warp/weft }\end{array}$ & $\begin{array}{l}\text { Linear } \\
\text { density of } \\
\text { threads, Tex } \\
\text { warp/weft }\end{array}$ & $\begin{array}{c}\text { Surface } \\
\text { filling, } E_{s} \%\end{array}$ & $\begin{array}{c}\text { Surface } \\
\text { porosity, } \\
\mathrm{R}_{\mathrm{s}} \%\end{array}$ \\
\hline 1 & Bamboo 100 & 114 & 0,21 & $350 / 320$ & $16,2 / 17,2$ & 74 & 26 \\
\hline 2 & Tensel 100 & 154 & 0,23 & $470 / 290$ & $20 / 19,3$ & 89 & 11 \\
\hline 3 & Linen 100 & 148 & 0,41 & $210 / 220$ & $42,4 / 30$ & 76 & 24 \\
\hline & Cotton 100 & 110 & 0,31 & $260 / 220$ & $20 / 26,3$ & 75 & 25 \\
\hline & $\begin{array}{l}\text { Cotton } 50 \\
\text { PE } 50\end{array}$ & 80 & 0,29 & $280 / 360$ & $15,3 / 20$ & 77 & 23 \\
\hline
\end{tabular}

Table 1: Structural characteristic of fabrics for hospital underwear

\begin{tabular}{|c|c|c|c|c|c|}
\hline 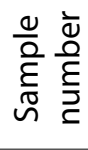 & $\begin{array}{c}\text { Raw material } \\
\text { composition, \% }\end{array}$ & $\begin{array}{c}\text { Air } \\
\text { permeability } \\
\mathrm{B}_{h}, \mathrm{dm}^{3} / \mathrm{m}^{2} \mathrm{c}\end{array}$ & $\begin{array}{c}\text { Moisture capacity, } \\
\text { W, \% }\end{array}$ & $\begin{array}{l}\text { Moisture capacity at horizontal } \\
\text { moisturizing, } \\
\qquad \mathrm{W}_{\mathrm{G}^{\prime}} \%\end{array}$ & $\begin{array}{c}\text { Area of drop run, } \\
\qquad, \mathrm{mm}^{2}\end{array}$ \\
\hline 1 & Bamboo 100 & 629 & 200 & 169 & 940 \\
\hline 2 & Tensel 100 & 300 & 87 & 88 & 1760 \\
\hline 3 & Linen 100 & 492 & 113 & 109 & 80 \\
\hline 4 & Cotton 100 & 567 & 104 & 105 & 1260 \\
\hline 5 & $\begin{array}{l}\text { Cotton } 50 \\
\text { PE } 50\end{array}$ & 321 & 80 & 68 & 314 \\
\hline
\end{tabular}

Table 2: Hygienic properties of fabrics for hospital underwear 
(Table 2) correlates with its values of surface filling and, accordingly, with the values of through porosity (Table 1). The highest air permeability has the sample of bamboo fabric with a sparse structure $\left(R_{s}=26 \%\right)$, the smallest - sample No. 2 of Tencel fibers with high weaving density $\left(R_{S}=11 \%\right)$.

A key factor of thermophysiological comfort when using hospital linen is the evacuation of moisture from clothing microclimate. The processes of absorption, transfer and desorption of moisture are determined by the peculiarities of the raw material composition and structure of used textile material. Assessment of moisture conductivity is a very actual task in the development of a model of moisture transfer, prediction of properties and the choice of materials for clothes.

The ability of a textile material to absorb water in direct contact with a liquid is characterized by capillarity and water absorption values. The capillarity, which was measured by the height $h$ of the fluid lifting in a sample immersed at one end into the liquid during one hour, characterizes the processes of moisture absorption by the longitudinal capillaries of the material. The obtained values of $h$ (Fig. 2) showed that in all tested samples capillarity is higher on the warp than on the weft, the highest value of capillarity has cotton fabric (sample No. 4), the lowest - both on the warp and on the weft - fabric from $50 \%$ cotton and $50 \%$ polyester fibers (sample No. 5). More rapidly, especially in the first 20 minutes, the liquid rises (Fig.2), in cotton and Tencel fibers, and this process passes very slowly in the mixed fabric (Sample No. 5).

High sweating, which is characteristic for ill patients, needs the rapid absorption of moisture as the most effective way of maintaining a sense of comfort. When used materials with high moisture absorption properties, sweat from the surface of the skin spreads rapidly throughout the fabric, providing dry feeling. Moisture capacity, determined by the standardized method, for the studied materials are quite different (Table 2). The lowest moisture content has the fabric sample No. 5. The ability of bamboo fabric (sample No. 1) to retain water in its structure twice or bigger in comparison with other samples. This is due the unique loose structure of bamboo fibers with a large volume of voids [4].

While wetting, the bamboo fibers absorb a considerable amount of water, noticeably increasing in transverse dimensions, which is contributes to the presence of a sufficiently large amount of through pores between threads. For comparison, we determined the values of air permeability and moisture content of another $100 \%$ bamboo fabric with a much denser structure, by satin weave. These values are much smaller than all other fabrics studied (Table 2). For all samples, the intensive process of water absorption occurs mainly in the first minutes (Fig. 3a). Then the fluid in the structure accumulates more slowly and after half an hour, almost all samples reach the level of maximum moisture saturation, which is almost unchanged.

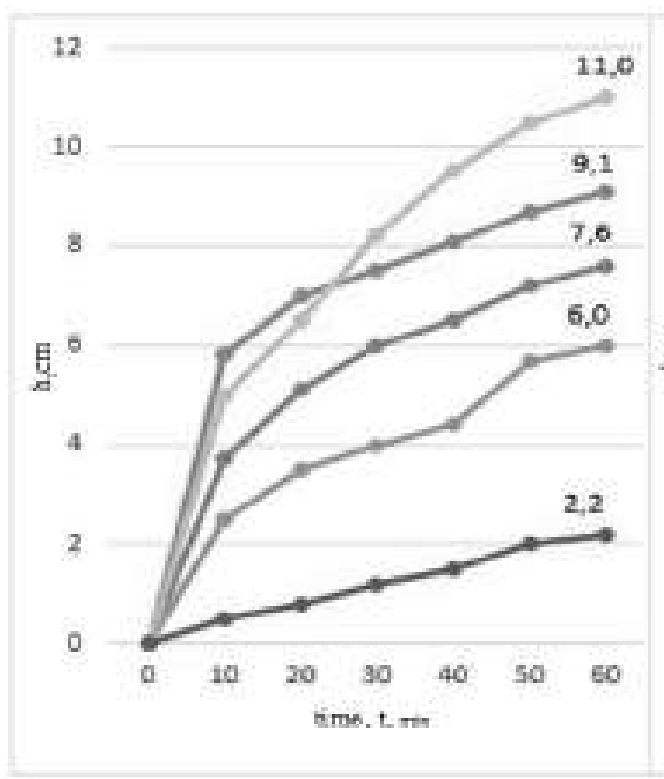

a)

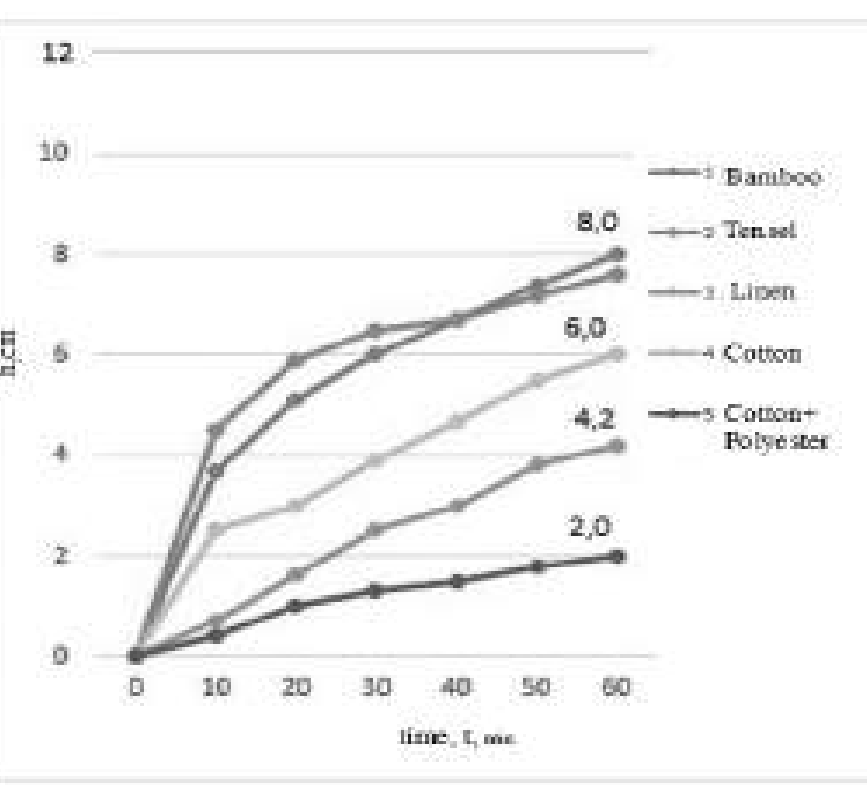

б)

Figure 2: Capillarity of the studied fabrics: a) on the warp, b) on the weft 


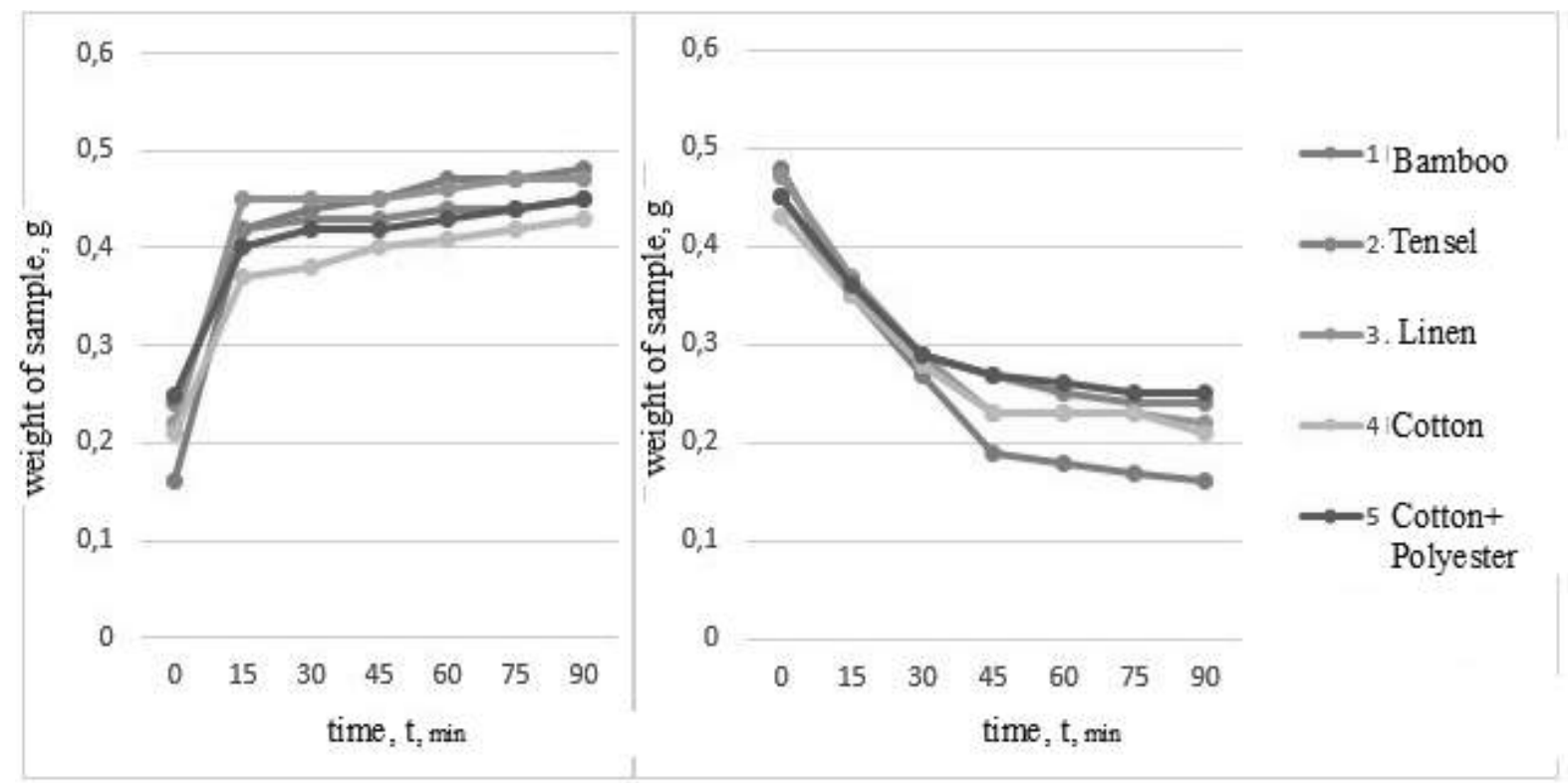

a)

б)

Figure 3: Changing of the weight of samples during wetting (a) and drying (b)

To ensure the comfort of hospital underwear, except the ability of materials to absorb liquid moisture, an important indicator of their quality is the intensity of the moisture loss process, which is determined by the rate of drying. The faster the moistened linen dries, the less the body of a sick person needs to expend energy on this process. To characterize the moisture output the drying time $\tau_{d}[\mathrm{~min}]$ was determined from the curves of the drying kinetics of the samples of materials after the study of moisture absorption. Overage of water from the sample surface was removed by squeezing the samples, which was placed between three layers of filter paper on both sides, by roller. Then the samples were dried at room temperature to reach constant mass, and every 10 minutes they were weighed using analytical weights. The curves of the drying kinetics (Fig. 3b) indicates that the fastest drying time (in half an hour) has sample No.5 from blended cotton/polyester fibers, for all other investigated fabrics the drying process is one and a half times longer.

Despite the peculiarities of the operating conditions, it should note that the materials of the hospital underwear are moistened, preferably under body pressure at horizontal contact with the source of moisturizing (sweaty skin of the lying patients). In order to determine the water absorption under conditions simulating this process, the following experiments has been done. A microfiber substrate uniformly moistened to the full saturation of the structure was placed in the Petri dish, covered by a sample of the fabric, the dimensions of which corresponded to the diameter of the dish. From above, through a thin layer of glass gasket, a load was imposed (Fig. 4a). The value of the load was calculated based on the data obtained [5] in measuring the pressure with which the body of the lying person acts on the bed - this value was 5000 $\mathrm{Pa}$. The amount of water absorbed by the sample of the material was fixed over time by analytical weights every 5 minutes. The difference in the mass of dry and wetted material for each step of the measurements allowed to evaluate the dynamic characteristic of the moisture absorption of the studied materials. Measurement deviations never exceeded \pm 3 units in the second significant digit after the decimal point, which determines the level of accuracy of the data obtained.

The moisture absorption kinetics curves obtained in these experimental conditions (Fig. 4b) indicate that the speed of reaching the maximum moisture saturation in the tested fabric samples, compared to the experiment conditions, when they are immersed in water, increased to half an hour. The values of $W$ in this method of moistening for all samples, except No. 1, practically coincide with those determined by the standardized method (Table 2), only for bamboo fabric the moisture capacity decreased by 1.2 times. Obviously, this may be due to the fact that the pore volume in the loose bamboo fibers decreases significantly under pressure. 

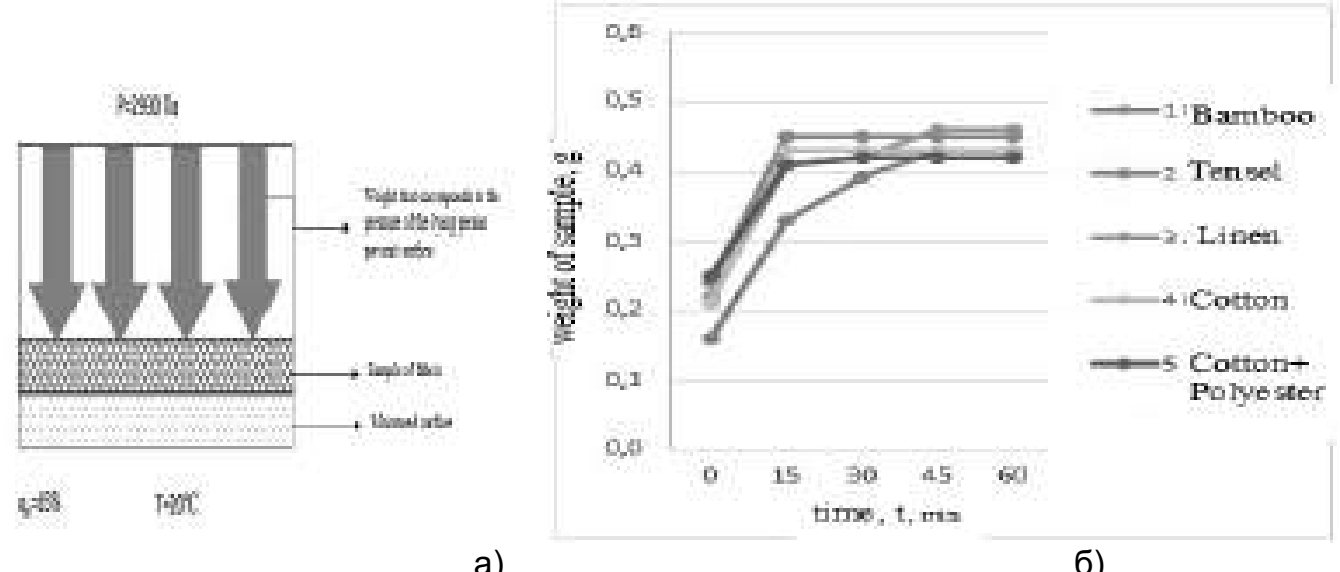

a)

б)

Figure 4: Scheme of the investigation (a); experimental kinetic curves of moisture absorption (b)

As an additional indicator to assess the ability of materials to absorb moisture in horizontal contact with the source of weing is often used indicator "area of a spread of the drop". For investigated fabrics of different raw material composition, the ability to distribute the liquid by pores, located in a horizontal position and at an angle relative to the source of moisture, differs significantly (Table 2.). Sample No. 2 has the largest spreading area of the droplet, a sufficiently large value of $\mathrm{S}$ demonstrates the cotton fabric (No. 4 ), and a very small area is created after the droplet spread in the structure of the linen fabric.

Using the obtained values of quality indicators, according to generally accepted method, a comprehensive assessment of the ability of materials to transfer moisture and air was carried out, with the calculation of the arithmetic mean of Ki. As the baseline values were chosen the best among those obtained for the test materials. According to the calculations, the highest value of Ki has bamboo fabric (sample No. 1), the second place - cotton fabric (sample No. 4), the lowest complex quality index in Tencel fiber fabric (sample No. 2).

\section{CONCLUSIONS}

The analysis showed that the values, obtained by standardized methods, which characterize the interaction of materials with liquid moisture, is advisable to supplement by methods adapted to the particular conditions of use of products. Thus, the definition of moisture absorption under the body pressure at the horizontal contact with the source of moisturizing allowed to more reasonably determine the material that is optimal in properties, which provides thermophysiological comfort when using hospital underwear.

\section{REFERENCES}

[1] Mitchell A, Spencer M., Edmiston C. (2015). Role of healthcare apparel and other healthcare textiles in the transmission of pathogens: a review of the literature. J Hosp. Infect. 90(4), 285 - 292.

[2] Waite M. (2010). Sustainable Textiles: the Role of Bamboo and a Comparison of Bamboo Textile properties (Part II). Journal of Textile and Apparel, Technology and Management. 6(3), 1 - 22.

[3] Nayak L., Mishra S.P. (2016). Prospect of bamboo as a renewable textile fiber, historical overview, labeling, controversies and regulation. Fash. Text. 2, 17-23.

[4] Firgo H., Schuster K. (2006). Suchomel F., Männer J., Burrow T., Abu-Rous M. The functional properties of TENCEL $^{\circledR}$ - a current update. Lenzinger Berichte. 85, $22-30$.

[5] Kovtun S., Arabuli A., Bereznenko S., Pavlova M. (2008). Investigation of man body pressure on a surface of bed linen for bed-patients. New materials and innovative technologies of manufacturing clothing and footwear. XI, 202 - 205.

Rad primljen: 18.02.2020.

Rad prihvaćen: 01.03.2020. 